\title{
Spear-grass pastures in south-east Queensland and their management
}

\author{
L. 'T MANNETJE \\ C.S.I.R.O. Division of Tropical Pastures, Cunningham Laboratory, Brisbane, \\ Queensland, Australia
}

\begin{abstract}
Summary
This paper describes native pasture in which Heteropogon contortus (L.) BEAUV. ex R. \& S. (black or bunch spear grass) is the dominant species. The effects of burning, stocking rate and soil fertility on the botanical composition of these pastures are discussed. It is concluded that the species composition is sensitive to management practices.

Improvement in the normally very low beef production may be obtained by including a legume in the sward with or without phosphorus, sulphur, potassium and molybdenum fertilizers or by completely replacing the indigenous species by introduced grasses and legumes with the use of these fertilizers. Higher beef production may also be obtained by adding the fertilizers to unimproved pastures, but the economics of such a measure are very doubtful.
\end{abstract}

\section{Introduction}

Spear-grass pastures cover an extensive area in eastern Queensland. The name is derived from the main component, Heteropogon contortus (L.) BeAuv. ex R. \& S., black or bunch spear grass. SHAw and BISSET (1955) estimated the total area at approximately 43 million acres in central and south-eastern Queensland, i.e. between Townsville and the southern border of the State (see FIG. 1). More than half of this area lies within the tropics.

These pastures are of great economic importance since they carry $25 \%$ of the beef cattle of Queensland. However, beef production per unit area is very low. A detailed account of the climate, which ranges from tropical to sub-tropical, is given by CoALDRAKE (1964). FIG. 2 shows monthly averages of rainfall for three stations within this region.

From December to March inclusive - i.e. the summer months - Townsville receives $76 \%$, Rockhampton $62 \%$ and Esk $52 \%$ of the total annual rainfall, and winter rainfall decreases from south to north. However, rainfall in most of Queensland is very unreliable and variability is great over the years. Droughts and floods are common features of the rainfall pattern. Temperatures follow a general pattern, as shown in FIG. 3.

Extremes in temperature are very important in their effect on plant growth. Light frosts are experienced in most of the spear-grass region, and their effect on pasture production is usually severe. Extreme high temperatures $\left(100^{\circ} \mathrm{F}\left(=38^{\circ} \mathrm{C}\right)\right.$ or more $)$ are also common, but their effects on plant growth are deleterious only when they are coincident with extended dry periods.

The soils are derived from various rock formations and are mainly podzolic or solodic in nature (HubBle, 1964); they are of low to medium fertility. The main nutrient

Received for publication 29th December, 1964.

Neth. J. agric. Sci., Vol. 13 (1965) No. 2 (June) 
FIG. 1. Map of south-east Queensland, showing the distribution of spear-grass (Heteropogon contortus) pastures

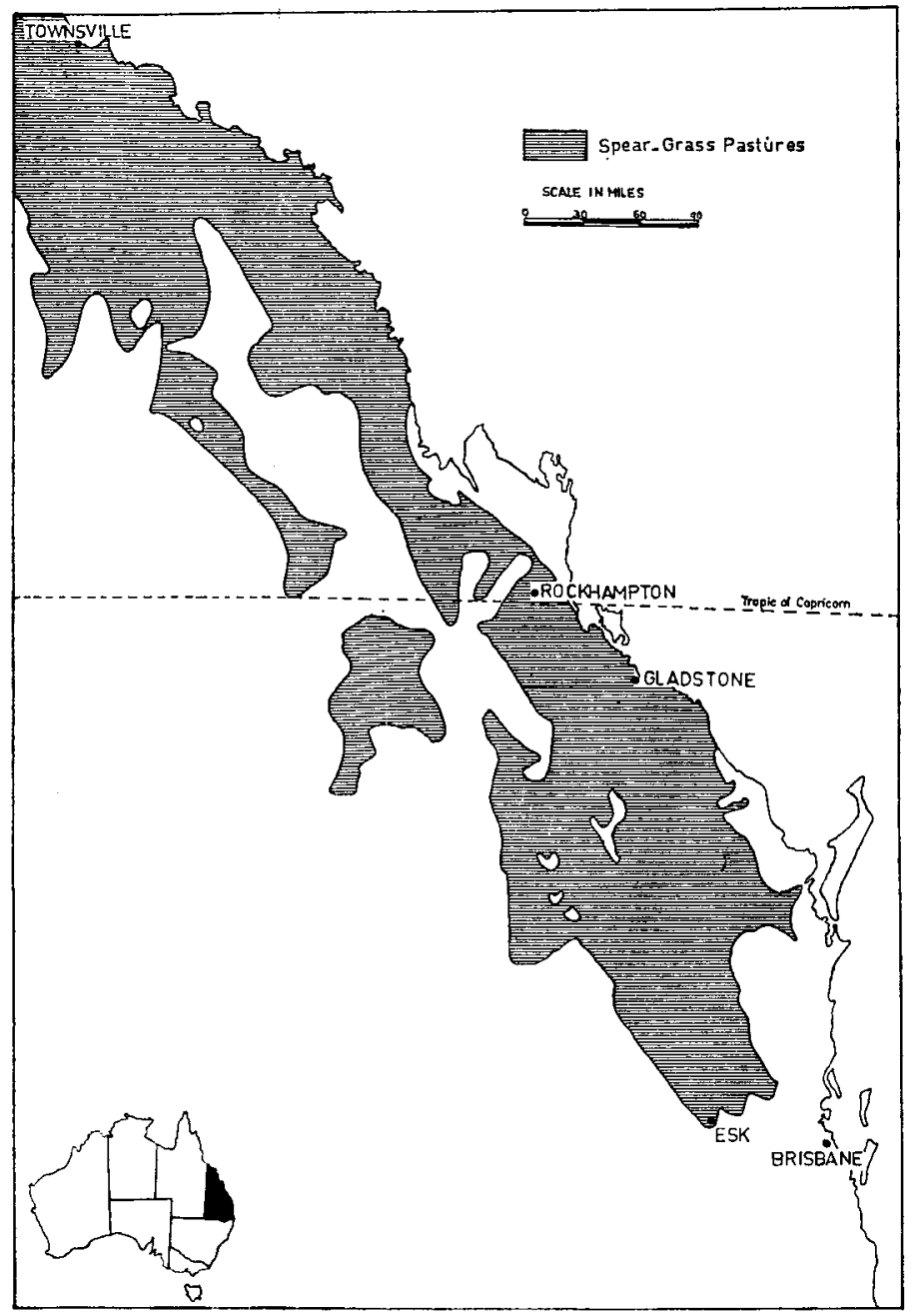

deficiencies for improved pastures are nitrogen, phosphorus, sulphur, potassium and molybdenum. However, fertilizers are not used on native pastures.

\section{Description of spear-grass pastures}

True natural grassland in Queensland is mostly restricted to the open plains of the inland and western parts of the State, which receive less than 20 inches of rain a year. In coastal and sub-coastal areas open sclerophyll forests (mainly Eucalyptus spp.) contain a herbaceous understorey which consists mostly of perennial grasses and very few perennial and annual legumes. Since European settlement, these forests have been thinned out and stocked with sheep and cattle. Unfortunately, the effects of these 

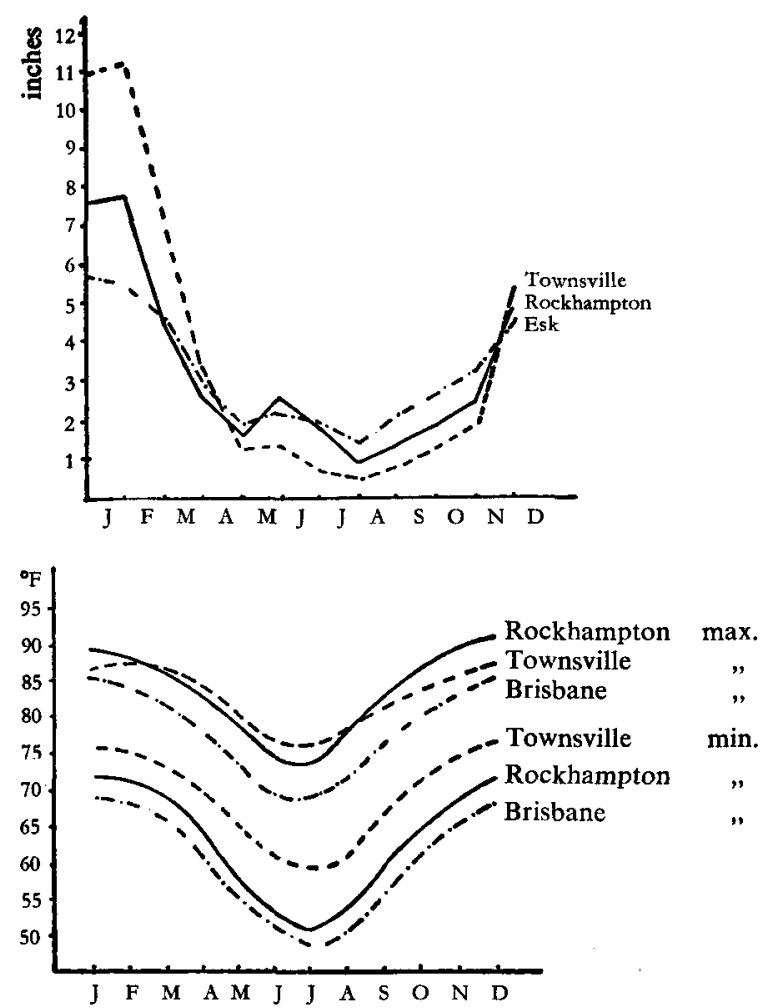

FIG. 2

Average monthly rainfall at three stations in south-east Queensland (data from Commonwealth Bureau of Meteorology, Melbourne, Australia)

\author{
Total annual rainfall for: \\ Townsville -45.72 inches \\ Rockhampton -39.28 inches \\ Esk $\quad-38.90$ inches
}

FIG. 3

Mean maximum and minimum daily temperatures at three stations in south-east Queensland (data from Commonwealth Bureau of Meteorology, Melbourne, Australia)

measures on botanical composition are not known accurately. It is generally accepted that Themeda australis (R. BR.) STAPF (kangaroo grass) originally dominated in these grasslands, but regular, continuous grazing by sheep and cattle, together with annual burning of the pastures, has made this palatable grass a minor constituent of the present-day native pastures. Its place has been taken by $H$. contortus.

Most of coastal and sub-coastal Queensland was used for sheep grazing by the early settlers, but from about 1880 onwards the properties changed over to cattle grazing. MURPHY and EASTON (1950) quote references from family diaries which support the hypothesis that the sheep industry was pushed out of the coastal and sub-coastal areas of the State because of the increase in spear-grass with its spear-like fruits, which are harmful to sheep and wool production. The probability of this change in botanical composition is further supported by the dominance of $T$. australis in burnt but ungrazed enclosures (railway lines, cemeteries) surrounded by burnt and grazed areas in which $H$. contortus is dominant. Dr. J. C. TothILl of this Laboratory has recently commenced a study of a pasture which contains a large proportion of $T$. australis as well as $H$. contortus to investigate the change in botanical composition when subjected to different treatments of grazing, burning and fertilizer applications.

The quantity and quality of herbage produced by spear-grass pastures is low, even during the period of active growth. SHAw and BISSET (1955) recorded total annual dry-matter yields of 2000 to $3000 \mathrm{lbs}^{\text {per acre }}{ }^{1}$ with annual burning in a pasture

$11 \mathrm{lb} /$ acre $=1.12 \mathrm{~kg} / \mathrm{ha}$. 
that consisted of up to $90 \%$ spear grass on a dry-matter basis. About $90 \%$ of this production took place between mid-October and mid-April. Rain between April and October had little effect on growth. Temperature is the likely limiting factor for pasture production during the cooler months, as was shown by MILes (1949). He found that dry-matter production followed mean daily maximum temperature very closely, and that good rainfall in winter, e.g. May, June, July and August, 1944, did not stimulate pasture growth (FIG. 4).

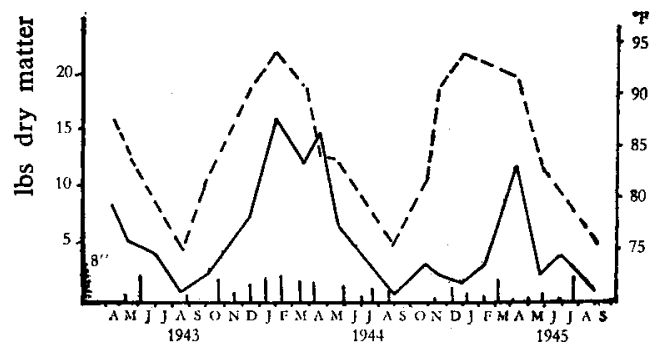

Fig. 4

Dry-matter production of a speargrass pasture, mean maximum daily temperatures and rainfall at Fitzroyvale near Rockhampton from 1943 to 1945 (MILES, 1949)

dry-matter production

.... mean daily maximum temperature

The nitrogen content of the pasture studied by SHAw and Bisset (1955) was below $1.6 \%$ even when the grass was very young, and decreased to $0.3-0.5 \%$ in winter. Winter rainfall aggravates this situation because of its leaching effect on the dry material. A generalized cumulative growth curve and the àcompanying nitrogen content are presented in FIG. 5.

Growth is rapid in the early part of the season, if sufficient moisture is available, and this is followed by early flowering ${ }^{1}$ and deterioration of quality.

At the end of the season a large amount of dead material usually remains, and this is burnt to permit cattle access to new growth.

These pastures are mainly used for beef cattle under continuous grazing for twelve months of the year, but beef production is very low. SHaw (1961) recorded live-

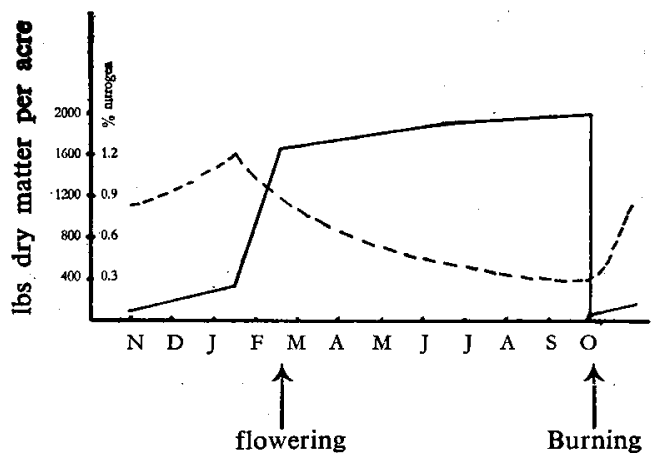

FIG. 5

Generalized growth curve with accompanying nitrogen content of unimproved spear-grass pastures in south-east Queensland

1 TOTHILL (1963) found variability within $H$. contortus with regard to flowering time. North of Townsville a late-flowering type occurs exclusively, whilst south of Townsville mixtures of earlyto late-flowering types may be found. 
weight gains of about $20 \mathrm{lbs}$ per acre per annum on a pasture which was grazed at the normal commercial rate of 1 animal per 9 acres. This low stocking rate is based on the low availability of good-quality herbage during winter time, although sufficient herbage of fair quality is available during the growing season for a much higher stocking rate. This results in undergrazing of these pastures during the summer, so that after a normal season a relatively large quantity of herbage remains uneaten. During the winter and spring period, cattle invariably lose weight, despite the standing "hay".

\section{Management}

\subsection{The effect of burning}

Fires caused by lightning as well as by the native inhabitants were already part of the Queensland environment before European settlement. Aborigines used to burn small areas to attract game to fresh shoots of grass. SHaw (1957) described the present practice of burning as follows:

At the end of winter a large bulk of old grass which is valueless as feed remains uneaten, and the grazier removes this by burning. In support of this practice it is said that the grasses shoot earlier if burnt, that the new growth is made more accessible to the grazing animal, and that stock do better on burnt country.

The effect of burning on the botanical composition of spear-grass pasture was studied by SHAW (1957). In the TABLE some of the results of this work are summarized.

The ground occupied by $H$. contortus had increased markedly in the "burnt" treatment, whereas its proportion was practically unchanged in the "mow and rake" treatment. Seedling counts in four years showed that the mean number of spear-grass seedlings per 100 square links ( 1 link $=7.92$ inches) in the "mow and rake" treatment was 2.7 , while in the "burning" treatment this was 421 ; of other grass seedlings these figures were 8 and 8.5 respectively. SHAw summarized the results as follows:

The main effect of burning was to give dominance of Heteropogon contortus, and it would appear that this arises from three main causes: established plants are resistant to fire, fire favours germination of seed, and fire reduces the ground cover of other species.

TABLE. Botanical composition as percentage ground cover of spear-grass pasture where the pasture was burnt or mown and raked annually since 1945. The observations were made in 1948 and 1953 (after SHaw, 1957)

\begin{tabular}{|c|c|c|c|c|}
\hline Species & & 1948 & & 1953 \\
\hline & burnt & $\begin{array}{l}\text { mown and } \\
\text { raked }\end{array}$ & burnt & $\begin{array}{l}\text { mown and } \\
\text { raked }\end{array}$ \\
\hline 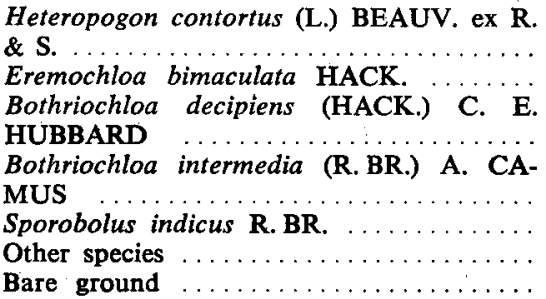 & $\begin{array}{r}1.0 \\
0.9 \\
13.8 \\
58.1\end{array}$ & $\begin{array}{r}3.1 \\
1.7 \\
12.2 \\
56.9\end{array}$ & $\begin{array}{r}2.6 \\
0.0 \\
6.2 \\
60.4\end{array}$ & $\begin{array}{r}7.2 \\
1.7 \\
9.7 \\
55.9\end{array}$ \\
\hline
\end{tabular}


The highest temperature recorded on the surface during a "normal" burning of a spear-grass pasture, i.e. 24 hours after 1 inch or more of rain in early spring, did not exceed $100^{\circ} \mathrm{C}$ (TothILl, 1964).

\subsection{The effect of grazing pressure and soil fertility}

Current work by SHAw and ' $T$ MANNETJE on the effects of various management practices on unimproved spear-grass pastures are showing interesting results. Where the normal stocking rate of 1 animal to 9 acres $(1: 9)$ has been increased to $1: 4$ without fertilizer, an appreciable decrease in the frequency per cent (F \%) of $H$. contortus has taken place, with a dramatic decrease in animal performance. Where fertilizer ( $P, S, K$ and $M o$ ) has been added and the stocking rate increased to $1: 4$, the main change in botanical composition has been an increase in indigenous legumes from $F \% 30$ to 60 , with a higher animal performance than under normal management. Where an exotic legume (Stylosanthes humilis H.B.K.) and fertilizer (P, S, K and $\mathrm{Mo}$ ) have been added, the stocking rate could be increased to $1: 2$ with a tenfold increase in animal production per unit area, without significant changes in the proportion of indigenous species.

The application of nitrogen fertilizer at levels from nil to $300 \mathrm{lbs} \mathrm{N} /$ acre/annum, in the presence of a basal application of $P, S$ and $K$, resulted in a linear increase of dry-matter production. In a good rainfall year the dry-matter yield per acre increased from $5000 \mathrm{lbs}$ without $\mathrm{N}$ to $16000 \mathrm{lbs}$ with $300 \mathrm{lbs} \mathrm{N} / \mathrm{acre}$. In a drought year these figures were 2400 and 4700 respectively. This experiment is being carried out in the absence of grazing and burning. The main change in botanical composition that is taking place is the replacement of a large proportion of $H$. contortus by broad-leaved weeds at $300 \mathrm{lbs}$ N/acre/annum ('T MANNETJE and SHAw, unpublished data).

The practical significance of these changes in botanical composition cannot be judged since the relative value of each species is not known. Of the indigenous grasses $H$. contortus is certainly not the least valuable one. In the early stages of its growth it is quite leafy and cattle prefer it then to many other species including exotic ones.

\section{Conclusion}

From the relatively little research that has been done on indigenous pastures in Queensland, it is clear that there is a vast area of unproductive pasture which is sensitive to changes in management.

Grazing experiments carried out by C.S.I.R.O. have shown that improvement in animal production can be obtained from native pasture by the use of fertilizer or the inclusion of a legume, such as $S$. humilis, with or without fertilizer, or by completely replacing the native pasture by sown grasses and legumes from other countries, with the addition of fertilizers. Of these practices "inclusion of a legume without fertilizers" is increasing rapidly in popularity. There are strong indications that the use of fertilizers on such pastures would be an economic proposition, but it is doubtful if the use of fertilizers on otherwise unimproved spear-grass pastures would be profitable. Completely sown pastures are still in the experimental stage and as yet no monetary data are available.

Most of C.S.I.R.O.'s research effort is directed towards improvement in beef production but ecological studies of indigenous pastures are considered to be of importance also. Work of DE VRIES (1948) and his co-workers in the Netherlands is an 
excellent example of how a descriptive study of old pastures can reveal characteristics of the environment. Vegetation mapping, as carried out by DE BoER (1956), is a direct application of the knowledge that was accumulated from the ecological work of DE VRIES. Modified methods of measuring the botanical composition would have to be used because of the different nature of the vegetation. Where DE VRIEs (1933) used a quadrat of $1 / 4 \mathrm{dm}^{2}$ with his "combined frequency and rank method" in dense and short Dutch pastures, a similar method used in Queensland (' $T$ MANNETJE and HAYDOCK, 1963) employs quadrats of 4 and $9 \mathrm{dm}^{2}$, because of the rather open and tall pastures encountered there. There is no reason to think that similar work in Queensland, supported by experimentation, would not also lead to valuable information regarding the environment.

\section{ACKNOWLEDGEMENTS}

The author wishes to thank Mr. N. H. Shaw and Mr. T. W. Elich, C.S.I.R.O., Division of Tropical Pastures, for constructive criticism of the manuscript and the final preparation of the figures, respectively.

BoER, T. A. DE

CoAldRake, J. E.

HubBLe, G. D.

MANNETJE, L. 'T, and

K. P. HAYDOCK

Miles, J. F.

Murphy, J. E., and

E. W. EASTON

Shaw, N. H.

and W. J. BISSET

TothilL, J. C.

VRIES, D. M. DE
1956 Een globale graslandvegetatiekartering van Nederland. Versl. Landbk. Onderz. No. 62.5, 69 pp.

1964 The sub-tropical environment of eastern Australia. (a) Climate. In: Some concepts and methods in sub-tropical pasture research. Bull. 47, Commonwealth Bureau of Pastures and Field Crops, Hurley, Berkshire, England.

1964 The sub-tropical environment of eastern Australia. (c) Soils. In: Some concepts and methods in sub-tropical pasture research. Bull. 47, Commonwealth Bureau of Pastures and Field Crops, Hurley, Berkshire, England.

1963 The dry-weight-rank method for the botanical analysis of pasture. J. Brit. Grassl. Soc. 18, 268-275.

1949 Plant introduction trials in central coastal Queensland. C.S.I.R.O. Aust., Div. Plant Industr. Rep. No. 6.

1950 Wilderness to Wealth. W. R. Smith \& Patterson Pty. Ltd., Brisbane.

1957 Bunch spear grass dominance in burnt pastures in southeastern Queensland. Aust. J. Agric. Res. 8, 325-334.

1961 Increased beef production from Townsville lucerne (Stylosanthes sundaica TAUB.) in the spear grass pastures of central coastal Queensland. Aust. J. Exp. Agric. Anim. Husb. 1, 7380.

1955 Characteristics of a bunch spear grass (Heteropogon contortus (L.) BEAUV.) pasture grazed by cattle in subtropical Queensland. Aust. J. Agric. Res. 6, 539-552.

1963 Spear grass. In: Annual Report 1962-63, C.S.I.R.O. Aust., Div. Trop. Past., Brisbane.

1964 Spear grass studies. In: Annual Report 1963/64, C.S.I.R.O. Aust., Div. Trop. Past., Brisbane.

1933 De rangorde methode. Een schattings methode voor plantkundig graslandonderzoek met volgorde bepaling. Versl. Landbk. Onderz. No. 39A, 1-24.

1948 De botanische samenstelling van Nederlandse graslanden. Versl. Landbk. Onderz. No. 54.8, 1-12. 